\title{
Journey of A Drug from Table to Trade
}

\author{
Shobith Rangappa* \\ Adichunchanagiri Institute for Molecular Medicine, BG Nagara, India
}

Received Date: July 19, 2018; Published Date: July 27, 2018

*Corresponding author: Shobith Rangappa, Adichunchanagiri Institute for Molecular Medicine, BG Nagara, Mandya, India,

Email: shobithrangappa@gmail.com

Abstract

The development of new drugs is a complex and expensive process which may nearly take around 5-10 years. The journey of drug molecule from lab to shelf involves a series of steps, which starts from the identification of a target molecule to drug approval. The exorbitant drug discovery program consumes massive amounts of funds and time before it reaches to the final drug approval.

\section{Target identification, validation and Identification of lead molecules:}

The journey of discovering new drug initiates in the laboratory or pharma company begins with identification of a precise target molecule (Target identification) with the help of Bioinformatics tools which may be a macromolecule i.e. DNA, RNA or Proteins, continues further to validate the target molecule [1]. Once the target validation process has performed, the next task is to identify a hit molecule which effectively binds to target. Identification of hit molecules from a huge chemical library is a Herculean task which will be simplified with the help of High throughput screening machine which can screen thousands of compounds with ease. As many as 1,00,000 compounds may be considered and scaled down to thousands by selecting the hits, which showing a certain degree of confidence and processed further as lead molecules [2].

The identified lead molecules have to be optimized further to process it into preclinical studies, this involves calculation of physio-chemical properties of lead compound for further refining the lead molecule using a 2D/3D QSAR approach (Quantitative structure and activity relationship). The lead molecules which are processed to preclinical studies should have an adequate pharmaceutical property which can be evaluated with Lipinski rule of 5 which is used to identify absorption and permeability issues in the lead molecules. Finally, the lead molecule should exhibit good ADME profile. The compounds which won't fulfill the above criteria will be eliminated and the potent lead molecules will be processed further for preclinical studies [3].

\section{Preclinical Studies}

Before taking it to clinical trials on humans, the lead molecule has to be subjected for safety evaluation to identify the potential ability of compound to exhibit harmful effects on humans; this will be accomplished by examining using cultured cells and laboratory animals in controlled conditions.

Preclinical studies will be carried out in 2 ways

i. In-Vitro assays

ii. In- Vivo assays

The identified lead molecules are subjected for pharmacokinetics, pharmacodynamics, toxicity profile, carcinogenicity profile and ADME tests by In-vitro and In-vivo assays using cultured cells and using laboratory model animals to discern the potential pharmaceutical property of a drug molecule to process further for clinical trials on human. Preclinical studies on animal models discern the dosage and toxicity profile of the lead molecule which is very much essential to process it further. Once all the safety assessment have been done the lead molecule will be processed further for IND (Investigational new drug) approval, if the candidate passes IND approval it will processed further to clinical trials on human.

\section{Clinical Trials}

Drugs which are stepped into clinical trials by passing preclinical studies were progressed through a stringent and highly regulated phase trials with four stages of phase trials on normal healthy volunteers and patients $[4,5]$.

\section{Phase studies}

i. Phase I studies: First human trial which includes more than 100-200 healthy volunteers which may last for 3-4 weeks this study discerns any side effects, toxic effects and pharmacological effect on humans.

ii. Phase II studies: After safety assessment of the drugs in phase I trials multiple doses of drugs will be tested on more 
than 300-500 volunteer patients with targeted disease, this stage of study elucidates minimum / maximum effective dosage, maximum tolerated dose and any common short time side effects of drugs on humans.

iii. Phase III studies: This is the penultimate trails before the drug registration which includes study on large population ranging from 2000-3000 with multi doses for longer time to evaluate the safety, effectiveness of the drug on larger population and any long term adverse side effects of the drug on humans.

iv. Phase IV studies (Post marketing trails): The final phase of a drug on large population ranging from 20003000 patients with targeted disease, this study reveals effect of drug on larger number of population, effectiveness of drug on large population, performs quality of life trails and gathers all safety and additional adverse effect of the drug and will proceeded further.

\section{Conclusion}

Development of new drug molecule is very essential for the modern world to fight against various existing and emerging diseases. Modern day technology like High throughput screening instrument, computer docking studies have improved the quality of research and minimized the human effort and splurging of huge funds. Modern day drugs have revolutionized, they have helped clinicians and physicians by eliminating complications which were involved in surgical removal of malignant tumors by its precise specificity towards its target by abolishing them without any surgery.

\section{References}

1. Singh S, Malik BK, Sharma DK (2006) Molecular drug targets and structure-based drug design: A holistic approach. Bioinformation 1(8): 314-320.

2. Hughes JP, Rees S, Kalindjian SB, Philpott KL (2011) Principles of early drug discovery. Br J Pharmacol 162(6): 1239-1249.

3. Pradeep KV, Dileep RJ, Pavan B (2013) Importance of ADME and Bioanalysis in the Drug Discovery. J Bioequiv Availab 5: e31.

4. Nishant T, Sathish Kumar D, Arun Kumar, Phaneendra M (2011) Role of Pharmacokinetic Studies in Drug Discovery. J Bioequiv Availab 3: 263-267.

5. Celikyurt IK (2011) Thought-provoking Molecules for Drug Discovery: antioxidants. Pharm Anal Acta S3:001

\begin{tabular}{|l|}
\hline Your next submission with Juniper Publishers \\
will reach you the below assets \\
- Quality Editorial service \\
- Swift Peer Review \\
- Reprints availability \\
- E-prints Service \\
- Manuscript Podcast for convenient understanding \\
- Global attainment for your research \\
- Manuscript accessibility in different formats \\
( Pdf, E-pub, Full Text, Audio) \\
- Unceasing customer service \\
Track the below URL for one-step submission \\
- https://juniperpublishers.com/online-submission.php \\
\hline
\end{tabular}

